\section{Analysis of discrepancies of core needle biopsy and surgical specimens for accurate evaluation of hormonal receptors and epidermal growth factor receptor 2 status of invasive breast cancer patients}

Ljiljana Tadić Latinović ${ }^{1}$, Živka Eri ${ }^{2}$, Darko Jović3 ${ }^{3}$,

Aleksandra Salapura ${ }^{1}$, Jovan Ćulum ${ }^{3}$, Branislava Jakovljević ${ }^{3}$,

Ilija Baroš ${ }^{1}$, Slavica Marić ${ }^{4}$

${ }^{1}$ Department of Pathology, University Clinical Center

of Republic of Srpska, Banja Luka, Republic of Srpska, Bosnia and Herzegovina

${ }^{2}$ Canter for Molecular Genetics, Institute for Pulmonary Diseases, Sremska Kamenica, Republic of Serbia

${ }^{3}$ Surgical Clinic "S-Tetik", Banja Luka, Republic of Srpska, Bosnia and Herzegovina

${ }^{4}$ International Medical Canters- Centar za Radioterapiju Banja Luka, Banja Luka, Republic of Srpska, Bosnia and Herzegovina

\section{Abstract}

Breast cancer is a serious health problem. It is the most common cancer in women. The aim of this study was to estimate the concordance between ER, PR receptor and HER-2 immunohistochemistry assessment scores in pared CNB (core needle biopsy) and surgical specimens. Histological grade, oestrogen receptor (ER) status, progesterone receptor (PR) status, and human epidermal growth factor receptor-2 (HER2) status were evaluated in a blinded fashion in CNB and in surgical excision specimens. Absolute concordance rate between core needle biopsies and surgical specimens for histological grade was $50 \%$ with $\kappa$ value $(0,15)$ for ER $92 \%$ with $\kappa$ value $(0,79)$, PR $88 \%$ with $\kappa$ value $(0,73)$ and for HER $296 \%$ with $\kappa$ value $(0,91)$. CNB can provide reliable information in evaluation of ER, PR and HER 2 status in an invasive breast carcinoma.

Ključne reči: breast cancer, core needle biopsy, oestrogen receptors, progesterone receptors, HER-2.

\section{Analiza odstupanja statusa hormonskih receptora i receptora za epidermalni faktor rasta 2 u uzorcima dobijenim iglenom biopsijom i hirurškim uzorkom kod obolelih od invazivnog karcinoma dojke}

\author{
Ljiljana Tadic Latinovic ${ }^{1}$, Zivka Eri², Darko Jovic ${ }^{3}$, \\ Aleksandra Salapura ${ }^{1}$, Jovan Culum ${ }^{3}$, Branislava Jakovljevic ${ }^{3}$, \\ Ilija Baros ${ }^{1}$, Slavica Maric ${ }^{4}$ \\ ${ }^{1}$ Department of Pathology, University Clinical Center \\ of Republic of Srpska, Banja Luka, Republic of Srpska, \\ Bosnia and Herzegovina \\ ${ }^{2}$ Canter for Molecular Genetics, Institute for Pulmonary Diseases, \\ Sremska Kamenica, Republic of Serbia \\ ${ }^{3}$ Surgical Clinic "S-Tetik", Banja Luka, Republic of Srpska, \\ Bosnia and Herzegovina \\ ${ }^{4}$ International Medical Canters- Centar za Radioterapiju Banja Luka, \\ Banja Luka, Republic of Srpska, Bosnia and Herzegovina
}

\section{Apstrakt}

Karcinom dojke je važan zdravstveni problem. To je najčešći karcinom kod žena. Cilj ove studije je da se odredi stepen podudarnosti između imunohistohemijskih skorova estrogenskih, progesteronskih i Her2 receptora kod iglenih biopsija dojke i odgovarajućih operativnih preparata. Evaluisani su histološki gradus, ER, PR i Her2 status u iglenim biopsijama i odgovarajućim operativnim preparatima. Apsoultna podudarnost histološkog gradusa je utvrđena u $50 \%$ slučajeva sa $\kappa$ vrednošću $(0,15)$, za ER $92 \%$ sa $\kappa$ vrednošću $(0,79)$, PR $88 \%$ sa $\kappa$ vrednošću $(0,73)$ i za Her2 96\% sa $\kappa$ vrednošću $(0,91)$. Iglene biopsije mogu obezbediti pouzdane informacije u evaluiranju ER, PR i Her2 statusa kod invazivnih karcinoma dojke.

Key words: karcinom dojke, iglena „core“ biopsija, estrogen receptor, progesteron receptor, HER-2.

\title{
Introduction
}

Breast cancer poses a serious health problem it is the most common cancer in women with an incidence of 464,000 new cases in Europe in 2012 causes of death 131,000. The mortality has decreased in western countries due to accurate diagnosis and optimal treatment ${ }^{1}$. The core needle biopsy (CNB) procedure is now established as the standard method for a diagnostic method for breast cancer and it is almost accurate as a surgical specimens deciding the optimal treatment algorithm ${ }^{2}$. The 2011 European Society of Medical Oncology breast cancer clinical practice guideline required a preoperative disease- related staging 
including determination of oestrogen receptor (ER), progesterone receptor (PgR) and human epidermal growth factor- 2 (HER2) status by immunohistochemistry (IHC) or in situ hybridization (ISH) ${ }^{3}$. Optimal determination of both ER, PgR and HER2 gene amplification is a subject of discussion. For breast cancer patients is very important to provide appropriate tissue samples for preoperative pathological analysis. Due to tumour heterogeneity and relatively smaller size of $\mathrm{CNB}$, the biomarker assessment performed on CNB samples may be less reliable than resection specimens. The information provided from CNB may be only information available for determining the patients for preoperative or neoadjuvant therapy. Particularly in settings where neo-adjuvant therapy is used the information obtained from CNB must reasonably reflect that in the whole tissue. Results of previous studies demonstrated that the concordance rate between CNB and surgical specimen were $61.7-99 \%$ for ER, 61,5-97,1\% for PgR and 80-96\% for HER2 respectively ${ }^{4}$.

Our aim was to estimate the concordance between ER, PgR receptor end HER-2 immunohistochemistry assessment scores in pared CNB and surgical specimens.

\section{Materials and Methods}

We studied 50 female patients with ductal invasive carcinoma NOS whose ages ranged from 28 to 81 (median ages 58). They underwent CNB and subsequent surgical treatment between January 2013 and 2014 in University Clinical Canter of Republic of Srpska. Patients who received neo- adjuvant therapy or radio/ chemo therapy between CNB and surgical excision were excluded from study. All the core biopsies were performed under ultrasound guidance using a 16- gauge true- cut needle. Surgical excision was performed in each case. After the CNB $25(50 \%)$ patients underwent quadrantectomy while total mastectomies was carried out in $25(50 \%)$ patients. During both procedures specimens were collected before the initiation of systemic treatment. All the specimens were fixed in $10 \%$ buffered formalin, embedded in paraffin, cut in to $4 \mu \mathrm{m}$ thick slices, staining with haematoxylin-eosin (HE) and immunohistochemically for ER, PgR and HER2, and placed on the glue- coated glass slides.

To determine ER and PgR status of each case, we used ER/PgR pharmDxTM (DAKO, Denmark) with the following antibodies: clones 1D5, ER-2-123 and clone PgR 1294, according to the manufacturer's instructions. All single-receptor positive cases were revaluated for ER and PgR stains. Repeat ER and PgR stains were reviewed by a pathologist blinded to clinical characteristics and tumour histology. Nuclear staining of any intensity was considered positive in all ER and PgR IHC staining cases. Also, to determine level of HER2 protein expression, we used Dako's pharmDx HercepTest according to the manufacturer's instructions. For epitope retrieval, we used The Epitope Retrieval Solution (HercepTest ${ }^{\mathrm{TM}}$ kit). Antibody we used was Rabbit Anti-Human HER2 Protein. Interpretation of the results is carried out by microscoping. To determine number of HER2 gene copies, we used HER2 CISH pharmDx ${ }^{\mathrm{TM}}$ Kit (DAKO Corporation, USA). After incubation at $60^{\circ} \mathrm{C}$ for $60 \mathrm{~min}$, the paraffin sections were deparaffinised in two series of xylol and rehydrated with ethanol series. Pre-treatment of the slides with (20x) solution (Dako, Denmark) in a water bath at $99^{\circ} \mathrm{C}$ for $10 \mathrm{~min}$ was followed by enzymatic digestion with ready-to-use pepsin for $4 \mathrm{~min}$ at $37^{\circ} \mathrm{C}$ on hybridizer (Dako, Denmark). Then, the slides were dehydrated and $10 \mu \mathrm{l}$ of HER2/cen17 probe was incubated to each tissue sections. Before the hybridization during the night at $37^{\circ} \mathrm{C}$, the slides and probe were denatured at $94^{\circ} \mathrm{C}$ for $5 \mathrm{~min}$. Then, the slides were washed with stringent wash buffer at $63^{\circ} \mathrm{C}$ for $10 \mathrm{~min}$ in a water bath. After dehydration, tissue sections were covered with $10 \mu \mathrm{C}$ CISH Antibody Mix for $30 \mathrm{~min}$ and then incubated with blue and red chromogen for $10 \mathrm{~min}$. Samples were contrasted with haematoxylin. Standard result revision, described as Tanner's paper, was used for the interpretation of HER2 CISH results. Slides from both CNB and the surgery were independently reviewed in a blinded fashion by two pathologists. The following factors were considered: histological grade, ER status, PgR status and HER2 status. In cases of inter-observer disagreement, a conclusion was reached after sufficient discussion. The histological grade was assigned using the Nottingham grading system5. The ER and PgR results were assessed semi-quantitatively using Allred's scoring system6. The results were categorized as positive when the total score (TS), expressed as the sum of the proportion score (PS) and the intensity score (IS), was more than two. With regard to HER2, membranous

MATERIA MEDICA • Vol. 32 • No. 1 • januar 2016. 
staining was graded as negative (score 0 or $1+$ ), weakly positive (score $2+$ ) and strongly positive (score $3+$ ). Agreement between the results from CNB and those from surgical excision was statistically analysed using the absolute concordance rate and $\mathrm{k}$ statistic values.

\section{Results}

\section{Histological grade}

The histological grade was assessed in 50 cases that were identified as invasive carcinoma by both $\mathrm{CNB}$ and subsequent surgical excision. At CNB grade I was present at the $8(16 \%)$ cases grade II at the 38 $(76 \%)$ cases and grade III at the $4(8 \%)$ cases while at the surgical excision grade I was evaluated et the 3 (6\%) cases, grade II at the $24(48 \%)$ cases and grade III at the $23(46 \%)$ patients. There was 50\% $(25 / 50$ cases) concordance (Table 1.) with a $\kappa$ statistic value of 0.15 . Based on the results of histological grade concordance, in 24 of the 25 discordant cases, the grade at CNB was lower, while in one cases, the grade at $\mathrm{CNB}$ was higher than in subsequent surgical excision. However, disagreement case was 1-grade discordant in 24 cases. In one case disagreement was 2-grades. In that case the grade at the CNB was 2-grades lower than in subsequent surgical excision.

\begin{tabular}{|c|c|c|c|c|}
\hline $\begin{array}{c}\text { Histology grade } \\
\text { CNB }\end{array}$ & \multicolumn{3}{|c|}{ Histology grade Surgical excision } & \\
\hline & I & II & III & \\
\hline I & $\mathbf{2}$ & 5 & 1 & $8(16 \%)$ \\
\hline II & 1 & $\mathbf{1 9}$ & 18 & $38(76 \%)$ \\
\hline III & 0 & 0 & 4 & $4(8 \%)$ \\
\hline & $3(6 \%)$ & $24(48 \%)$ & $23(46 \%)$ & $\mathbf{5 0}$ \\
\hline
\end{tabular}

Absolute concordance rate, 50\% (25/50); kappa statistic value, 0.15 .

Table 1. Comparison of the histological grade in CNB and surgical excision

\section{Oestrogen receptor and Progesterone receptor}

At the CNB ER 38 (76\%) patients had ER and 34 (68\%) PgR positive. At the surgical excision, ER was expressed in $72 \%(36 / 50)$ of the cases, while PgR was expressed in $64 \%(32 / 50)$ of the cases (Table 2. and Table 3).

\begin{tabular}{|l|l|l|l|}
\hline \multirow{2}{*}{ ER CNB } & \multicolumn{2}{|c|}{ ER Surgical excision } & \\
\hline & Positive & Negative & \\
\hline Positive & 35 & 3 & $38(76 \%)$ \\
\hline Negative & 1 & 11 & $12(24 \%)$ \\
\hline & $36(72 \%)$ & $14(28 \%)$ & $\mathbf{5 0}$ \\
\hline
\end{tabular}

Absolute concordance rate, 92\% (46/50); kappa statistic value, 0.79.

Table 2. Comparison of ER in CNB and surgical excision 
ER/PR status of the excisional specimen was regarded as the golden standard. The sensitivity of CNB was $97,3 \%$, specificity $82,4 \%$ and positive predictive value $92,2 \%$ in ER. The sensitivity of CNB was $94,1 \%$, specificity $81,1 \%$ and positive predictive value $88,9 \%$ in PgR.

The number of discordant cases in ER was four ( $8 \%$ ). Among these, one (2\%) case was negative at CNB but positive at excision. Three (6\%) cases were positive at CNB but negative at excision. There was $92 \%$ concordance with a statistic value of 0.79 .

The number of discordant cases in PgR was six (12\%). Among these, two cases were negative at CNB but positive at excision. Four cases were positive at CNB but negative at excision. There was $88 \%$ concordance with a $\kappa$ statistic value of 0.73 .

\begin{tabular}{|l|l|l|l|}
\hline \multirow{2}{*}{ PgR CNB } & \multicolumn{2}{|c|}{ PgR Surgical excision } & \\
\hline & Positive & Negative & \\
\hline Positive & $\mathbf{3 0}$ & 4 & $34(68 \%)$ \\
\hline Negative & 2 & $\mathbf{1 4}$ & $16(32 \%)$ \\
\hline & $32(64 \%)$ & $18(36 \%)$ & $\mathbf{5 0}$ \\
\hline
\end{tabular}

Absolute concordance rate, $88 \%$ (44/50); kappa statistic value, 0.73 .

Table 3. Comparison of PgR in CNB and surgical excision

\section{HER2}

HER 2 was also evaluated in 50 cases. In $16(32 \%)$ of the 50 cases, HER 2 was expressed in the excisional specimen. For the CNB HER2 results, 24 (48\%) tumours were 0, 1+,10 (20\%) were $2+$ and $16(32 \%)$ were $3+$. For the resection specimens, $28(56 \%)$ tumours were $0,1+, 8(16 \%)$ were $2+$ and $14(28 \%)$ were $3+$. When comparing the results between CNB and resection specimens using the three IHC scores $(0$ or $1+$, $2+, 3+)$, we observed a significant number of discordant results. A total of 5 tumours were discordant for these three scores and 45 were concordant (90\%). These concordances do not all have clinical implications. We also assessed HER2 status as a dichotomous variable (HER2 negative/HER2 positive) according to the current HER2 testing protocols. If the tumour was scored as 0or 1+, the tumour was HER2 negative. Tumours with $2+$ scores were subjected to chromogen in situ hybridization assay (CISH). There was $96 \%$ (48/50 cases) agreement with a $\kappa$ statistic value of 0.91 . The sensitivity was $100 \%$, specificity $94,4 \%$ and positive predictive value $88,9 \%$ of CNB respectively (Table 4 ).

\begin{tabular}{|l|l|l|l|}
\hline \multirow{2}{*}{ HER 2 CNB } & \multicolumn{2}{|c|}{ HER 2 Surgical excision } & \\
\hline & Positive & Negative & \\
\hline Positive & $\mathbf{1 6}$ & 2 & $18(36 \%)$ \\
\hline Negative & 0 & $\mathbf{3 2}$ & $32(64 \%)$ \\
\hline & $16(32 \%)$ & $34(68 \%)$ & $\mathbf{5 0}$ \\
\hline
\end{tabular}

Absolute concordance rate, 96\% (48/50); kappa statistic value, 0.91 .

Table 4. Comparison of HER 2 in CNB and surgical excision 
In a two case where the score was $3+$ (strongly positive) at $\mathrm{CNB}$ at the surgical excision in one case score was 0 (negative ) at the surgical excision and in other case score was $2+$ (weakly positive) and after CISH testing result was negative. In three cases at the CNB score was $2+$ (weakly positive) with negative result after CISH testing, and in the same cases et the surgical excision score was 0 (negative).

\section{Discussion}

Accurate determination of histological type, grade, ER, PgR expression and HER2 gene amplification on invasive breast cancers is essential for optimal choice of (neo) adjuvant therapies. Multiple studies have investigated the concordance between CNB and resection specimens, usually with small patient series and with occasionally discrepant results.

In this study, we evaluated the histological grades of specimens taken at CNB and compared these with those of specimens taken at surgical excision. In particular, the histological grade is a powerful prognostic factor of invasive breast carcinoma. There was concordance $50 \%$ cases with a $\kappa$ value $(0.15)$. These result is lower to those reported previously $(59-75 \%)^{7-11}$. In the discordant cases, the grade at CNB tended to be lower than that at surgical excision. Previous studies noted that this tendency of the histological grade was due to underestimation of the mitotic count at CNB.

The hormone receptor status is also a very important and independent prognostic factor in breast cancer. In our study, hormone receptors were accurately evaluated at CNB. An almost perfect $\kappa$ value (0.79) in ER and a substantial $\kappa$ value (0.73) in PgR were observed. The concordance of PgR was lower than that of ER. This can be associated with the lower incidence of PgR-expressing cells in the whole tumour because the Allred total score of PgR (mean: 4.0) was lower than that of ER (mean: 5.3). Although the immunohistochemically staining results for $\mathrm{ER} / \mathrm{PgR}$ at $\mathrm{CNB}$ may be reliable for determining therapeutic indications. Four discordant cases (8\%) were observed in ER testing. There was one case that was CNB-negative and excision positive and three cases that were of the opposite type for ER assessment. Six discordant cases (12\%) were observed in PgR testing. There were two case that ware CNB-negative and excision positive and four cases that were of the opposite type for PgR assessment. The characteristics of the former cases are mainly due to intratumoral heterogeneity and some investigators ${ }^{12,13}$ have noted that such situations could exist because of more rapid and constant fixation. Douglas-Jones et al. ${ }^{14}$ suggested that ER expression was higher in the CNB than in the excised tumours. ER expression was higher at the periphery of tumours than at the canter. The higher ER expression in CNB might reflect the greater possibility of the peripheral part of a tumour being sampled when CNB is performed. CNB ER+/resection specimen ER-tumours were described in 1 patient (2\%) and CNB PgR+/resection specimen ER- tumours were described in one patient (2\%). Our study provides strong evidence that ER and PgR status can be reliably determined on the CNB. The number of patients misdiagnosed should not to be underestimated. We therefore recommend retesting ER-negative biopsies on the surgical specimen. HER2 positivity on either CNB or surgical specimen is an indication for treatment with the HER2-inhibiting drug such as trastuzumab. Concordance for HER2 IHC testing for the three categories $(0$ or $1+, 2+, 3+)$ has revealed that significant discordance exists between CNB and resection specimens ${ }^{15,16}$. Our study examined the concordance when examining HER2 status as positive or negative (determined with both IHC and in situ hybridization for $2+$ cases). The HER2 status, the diagnostic accuracy (particularly the sensitivity) of CNB was high with concordance of $96 \%$ and $\kappa$ value of 0,91 . We found one tumour $(2 \%)$ that was strongly positive $3+$ on the $\mathrm{CNB}$, but negative on the resection specimen one tumour ( $2 \%$ ) that was strongly positive $3+$ on the CNB and weakly positive $2+$ on the surgical specimen and negative afrer in situ hibridisation testing. In this study three tumours (6\%) showed weak positivity $2+$ on CNB with negative result after in situ hibridisation and on surgical resections they were negative with 0 score. The confirmation of $3+$ HER 2 results on CNB with in situ hybridization assays could be increase the indication for trastuzumab selection ${ }^{17,18}$. 


\section{Conclusions}

Concordance between CNB and surgical specimens was high for ER, PgR and HER2 testing. Core biopsy can provide reliable information on histological grade, hormone receptors and HER2 status of patients.

\section{References}

1. Ferlay J, Steliarova-Foucher E, Lortet-Tieulent J, Rosso S, Coebergh JWW, ComberH at al. Cancer incidence and mortality patterns in Europe: Estimates for 40 countries in 2012. Eur J Cancer 2013; 49:1374-1403.

2. Christopher J, Cimino-Mathews A, Park BH, Emens LA, Tsangaris TN, Argani P. Reflex Estrogen receptor/Progesteron receptor/Human epidermal growth factor receptor 2 (Er/PR/Her2) Analysis of Breast Cancers in Needle Core Biopsy Specimens Dramaticlly Increases Health Care Costs. Am Surg Pathol 2015; 39:939-947.

3. Dekker TJA, Smit VTHBM, Hooijer GKJ, Van de Vijver MJ, Mesker VE, Tollenaar RAEM at al. Reliability of core needle biopsy for determining ER and HER2 status in breast cancer. Ann Oncol 2012; 4:1-7.

4. Kentaro T, Sasano H, Ishida T, Takeda M, Amari M, Tamaki N at al. Comparison of core needle bipsy (CNB) and surgical specimens for accurate preoperative evaluation of ER, PgR, and HER 2 status for breast cancer patients. Cancer Sci 2010; 101:2074-2079.

5. Elston CW, Ellis IO. Pathological prognostic factors in breast cancer. I. The value of histological grade in breast cancer: experience from a large study with long-term follow-up. Histopathology 1991; 19:403-10.

6. Allred DC, Harvey JM, Berardo M, Clark GM. Prognostic and predictive factors in breast cancer by immunohistochemical analysis. Mod Pathol 1998; 11:155-68.

7. Andrade VP, Gobbi H. Accuracy of typing and grading invasive mammary carcinomas on core needle biopsy compared with the excisional specimen. Virchows Arch 2004; 445:597-602.

8. Sharifi S, Peterson MK, Baum JK, Raza S, Schnitt SJ. Assessment of pathologic prognostic factors in breast core needle biopsies. Mod Pathol 1999; 12:941-5.

9. Harris GC, Denley HE, Pinder SE, Lee AH, Ellis IO, Elston CW, et al. Correlation of histologic prognostic factors in core biopsies and therapeutic excisions of invasive breast carcinoma. Am J Surg Pathol 2003; 27:11-15.

10. Monticciolo DL. Histologic grading at breast core needle biopsy: comparison with results from the excised breast specimen. Breast J 2005; 1:9-14.

11. Badoual C, Maruani A, Ghorra C, Lebas P, Avigdor S, Michenet P. Pathological prognostic factors of invasive breast carcinoma in ultrasound-guided large core biopsies. A correlation with subsequent surgical excisions. Breast 2005; $14: 22-7$.

12. Xiaosong C, Long S, Yan M, Siji Z, Siji Z, Jiayi W at al. Preoperative core needle biopsy is accurate in determining molecular subtypes in invasive breast cancer. BMC Cancer 2013; 13: 390-396.

13. Sutela A, Vanninen R, Sudah M, Berg M, Kiviniemi V, Rummukainen J, et al. Surgical specimen can be replaced by core samples in assessment of ER, PR and HER-2 for invasive breast cancer. Acta Oncol 2008; 47:38-46.

14. Douglas-Jones AG, Collett N, Morgan JM, Jasani B. Comparison of core oestrogen receptor (ER) assay with excised tumour: intratumoral distribution of ER in breast carcinoma. J Clin Pathol 2001; 54:951-5.

15. Wojnar A, Pula B, Podhorska Okolow M, Dziegiel P. Discrepancies between HER2 assessment from core needle biopsies and surgical specimens of invasive ductal breast carcinoma. Adv Clin Exp Med 2013; 22:27-31.

16. Park YJ, Youk JH, Son EJ, Gweon HM, Kim JA. Comparison of hormonal receptor and

17. HER2 status between ultrasound-guided14-gauge core needle biopsy and surgery in breast cancer patients. Ultrasonography 2014; 33:206-215

18. Sarode VR, Xiang OD, MD; Alana MS, Collins R, Rao R, Leitch AM at al. Evaluation of HER2/neu Status by Immunohistochemistry Using Computer-Based Image Analysis and Correlation With Gene Amplification by Fluorescence In Situ Hybridization Assay. Arch Pathol Lab Med 2015; 139:922-928.

19. Stoss OC, Scheel A, Nagelmeier I, Schildhaus HU, Thomas Henkel T, Viale G at al. Impact of updated HER2 testing guidelines in breast cancer-re-evaluation of HERA trial fluorescence in situ hybridization data. Mod Pathol $2015 ; 281528-1534$.

Autor za korespondenciju

Autor: Prof. Ljiljana Tadić Latinović

Adresa: Zavod za patologiju, UKC RS, Dvanaest beba BB, 78000 Banja Luka, Republika Srpska, BiH Tel: +38751342333, mobilni: +38765785815

Email: lj.tadic@yahoo.com 